\title{
Checklist of the genus Niphargus Schiödte, 1849 (Amphipoda: Niphargidae) in Serbia, with some remarks on their distributions
}

\author{
Список видов рода Niphargus Schiödte, 1849 (Amphipoda: \\ Niphargidae) в Сербии с некоторыми замечаниями по их \\ распространению
}

\author{
Matija Petković ${ }^{1,2}$, Dragana Miličić1, Vladimir Tomić1, \\ Slobodan Makarov ${ }^{1}$

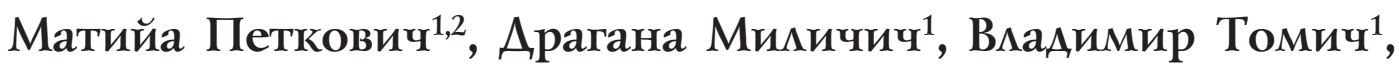 \\ Слободан Макаров ${ }^{1}$
}

\footnotetext{
${ }^{1}$ Institute of Zoology, Faculty of Biology, University of Belgrade, Studentski trg 3, 11000 Belgrade, Serbia. E-mail: slobodan@bio.bg.ac.rs

${ }^{2}$ Serbian Biospeleological Society, Trg Dositeja Obradoviæa 2, 21000 Novi Sad, Serbia.
}

KEY WORDS: Amphipoda, Niphargus, Serbia, checklist, freshwater.

КЛЮЧЕВЫЕ СЛОВА: Amphipoda, Niphargus, Сербия, контрольный список, пресная вода.

ABSTRACT. Twenty-two species of the genus Niphargus Schiödte, 1849 (Amphipoda: Niphargidae), including 14 strictly steno-endemic species, are known from the territory of Serbia. There are an additional 5 species which probably inhabit the same area, but data indicating their presence are doubtful and remain unconfirmed so far. Distinctive morphological characters of the species are listed, including all known localities and the presumed distributions.

How to cite this article: Petković M., Miličić D., Tomić V., Makarov S. 2020. Checklist of the genus Niphargus Schiödte, 1849 (Amphipoda: Niphargidae) in Serbia, with some remarks on their distributions // Arthropoda Selecta. Vol.29. No.4. P.433-442, Appendix. doi: 10.15298/arthsel. 29.4.05

РЕЗЮМЕ. Двадцать два вида рода Niphargus Schiödte, 1849 (Amphipoda: Niphargidae), включая 14 стено-эндемичных, известны с территории Сербии в настоящее время. Вероятно, есть еще 5 видов, которые, обитают здесь же, но данные об их наличии сомнительны или не подтверждены. Морфологические признаки для определения указанных видов представлены со всеми известными локалитетами и предполагаемым распространением.

\section{Introduction}

The order Amphipoda, part of the class Malacostraca, is highly diverse, currently including 10,273 species divided into six suborders (http://www. marinespecies.org/amphipoda/index.php).

The first record of a niphargid species was the description of Gammarus puteanus by C.L. Koch in 1836. The family Niphargidae was established much later, by Stanko Karaman in 1962 [Karaman, 1962]. Stanko and his son Gordan contributed significantly to the expansion of knowledge concerning the niphargids and described over 100 new species alone or in coauthorship. At present, the family Niphargidae is composed of 11 genera. There are approximately 30 known amphipod fossils, including several Eocene-Oligocene niphargids preserved in amber [Jazdzewski, Kupryjanowicz, 2010].

The genus Niphargus Schiödte, 1849 numbers close to 400 described species, which makes it one of the largest genera of freshwater amphipods in the world [Väinölö et al., 2008]. The majority of species can be found exclusively in subterranean waters [Zagmajster et al., 2014]. Higher taxonomy is still problematic, even with an annually growing species richness confirmed by molecular [Meleg et al., 2013] and morphological approaches [Ntakis et al., 2015]. Cryptic niphargid species are being detected increasingly often [Mathieu et al., 1997; Lefébure et al., 2006, 2007; Trontelj et al., 2009], which makes an integrative approach necessary. Differences between species can be minor. In contrast, differences between populations of the same species can be significant.

The Balkan Peninsula is known as a hotspot of biodiversity of the genus Niphargus. The country richest in species is Croatia, inhabited by 59 species, followed by Slovenia with 50, Romania - 39, Bosnia and Herzegovina - 23, Serbia - 22, Montenegro 21, North Macedonia — 20, Greece - 19, Bulgaria 11 and Albania with only one recorded species (according to Horton et al. [2019]), counting 189 loci typici citations of all valid species originated from this general area. An even greater diversity is expected in some regions, but there is paucity of information about 

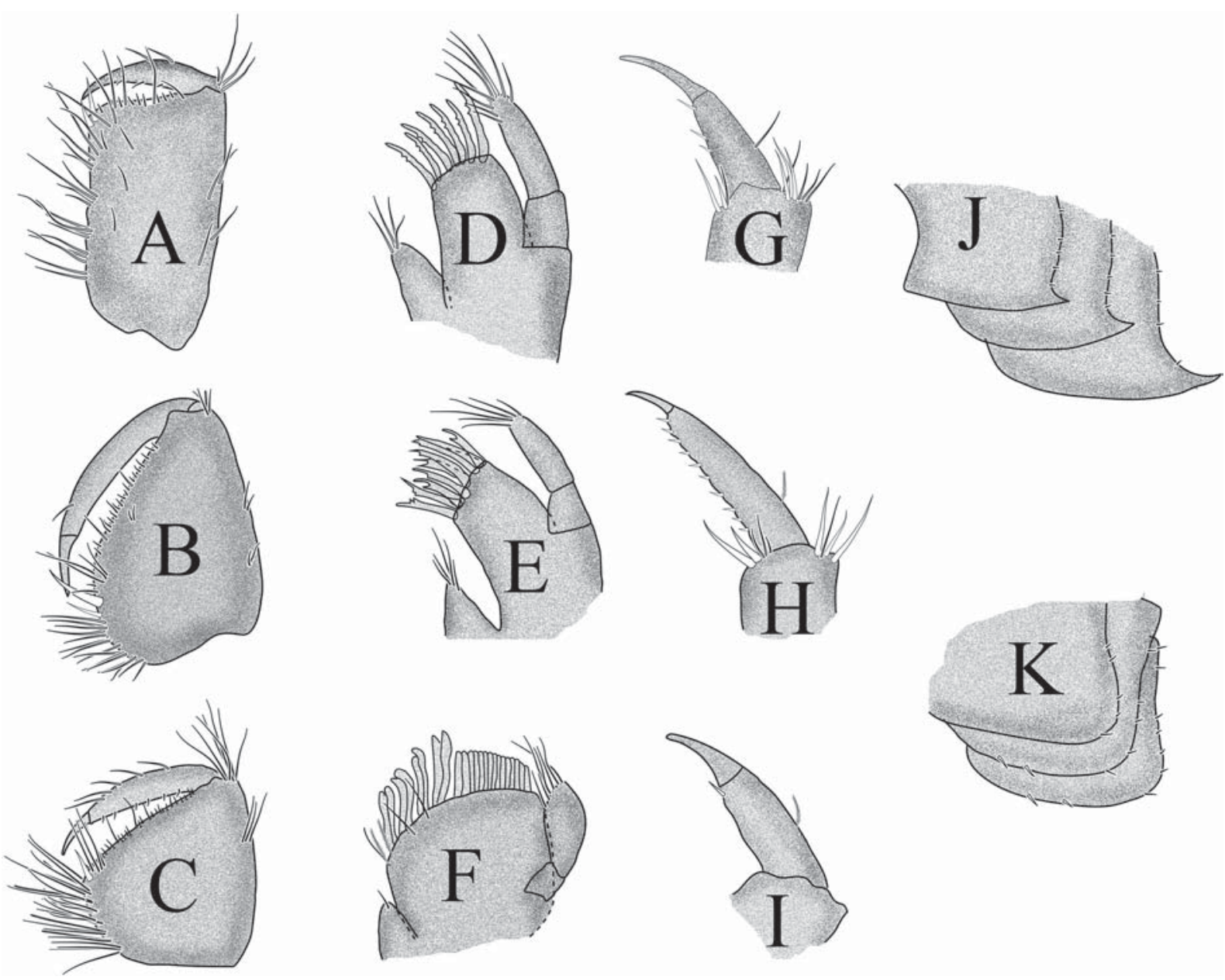

Fig. 1. Some highly distinctive and stable characters in Niphargus species inhabiting Serbia. Images are not displayed in the real ratio of dimensions. Gnathopod - A: N. jugoslavicus [after G. Karaman, 1982a], B: N. bajuvaricus [after G. Karaman 1989], C: N. luka [after G. Karaman, 2013a]. Maxilla I — D: N. euserbicus [after G. Karaman, 2012b], E: N. remyi [after G. Karaman, 2012a], F: N. caspary [after G. Karaman 1982b]. Dactylus of pereopod - G: N. illidzensis [after S. Karaman, 1950a], H: N. valachicus [after S. Karaman 1950c], I: $N$. bogdani [after G. Karaman, 2009]. Epimeral plates — J: N. valachicus [after S. Karaman, 1950c], K: N. euserbicus [after G. Karaman, 2012b].

Рис. 1. Некоторые из самых ярких и стабильных признаков у видов Niphargus, населяющих Сербию. Изображения не соотносятся с реальными размерами. Гнатопод - A: N. jugoslavicus [по: G. Karaman, 1982a], B: N. bajuvaricus [по: G. Karaman 1989], C: N. luka [по: G. Karaman, 2013a]. Maxilla I — D: N. euserbicus [по: G. Karaman, 2012b], E: N. remyi [по: G. Karaman, 2012a], F: N. caspary [по: G. Karaman 1982b]. Палец переопода — G: N. illidzensis [по: S. Karaman, 1950a], H: N. valachicus [по: S. Karaman 1950c], I: N. bogdani [по: G. Karaman, 2009]. Эпимеральные пластинки - J: N. valachicus [по: S. Karaman, 1950c], K: N. euserbicus [по: G. Karaman, 2012b].

their existence and a restricted number of ecological publications, probably due to the inaccessibility of their habitats and difficulties in obtaining specimens.

The first described niphargid species from Serbia is Niphargus remyi S. Karaman, 1934 from the Čedovo spring near the city of Sjenica in southwestern Serbia [Karaman, 1934]. Phylogeny of the species inhabiting Serbia was recently explored on the basis of molecular data by Petković et al. [2015] in a paper which is the first general study of niphargids in the area. At the same time, this paper contains the first record of the lake ecomorph N. mirocensis Petković et al., 2015 in the Carpathian Mountains.
Due to the inaccessibility of their habitats, the availability of sampled specimens is usually low. For example, N. adbiptus G. Karaman, 1973 [G. Karaman, 1973b] and N. remyi [S. Karaman, 1934] have not been documented since their originally collections. Remote sampling methods are usually non-selective and, therefore, non-effective, which makes caving and cave diving as the best possible ways to collect material. In addition, the somewhat controversial taxonomy and usual identification using a combination of several taxonomic characters, makes species identifications of the genus Niphargus hard. For all above reasons, it is hard to determine the real diversity and the level of endemicity 
within such group difficult to study. Therefore, it is very important to simplify the identification of species as much as possible for the scientific community, at least in the case of species found in Serbia.

The aim of this paper is to summarize the knowledge about the diversity of species of the genus Niphargus in Serbia and to discuss their current status and distributions. We provide an annotated list of all Serbian niphargids, with a brief explanation of highly distinctive morphological characters important for species identification.

\section{Material and methods}

All published and unpublished data regarding records of niphargid species from Serbia were collected and summarized. The type localities were revisited in order to confirm the presence of specimens and to collect topotypes, fresh material for preservation and further processing. Sampling conducted in all known caves or other appropriate nearby localities was made in the case of endemic species. Precise coordinates of type localities were taken, when it was possible, since all previously available data were mainly descriptive. The majority of samples and holotypes of all described species are deposited in the collection of Academician and Professor Emeritus Dr. Gordan S. Karaman in Podgorica, Montenegro, as well as in the private collection of Matija Petković in Valjevo, Serbia. Recent material collected by M. Petković is fixed in $60 \%$ ethanol, while some specimens are kept in $96 \%$ ethanol for future DNA extraction.

The collected specimens were processed at the Institute of Zoology, Faculty of Biology, University of Belgrade, Serbia. For the identification, niphargid individuals were cooked in a $10 \% \mathrm{KOH}$ solution, then briefly rinsed with diluted $\mathrm{HCl}$ and washed in distilled water. Cleared exoskeletons were stained with chlorazol black in glycerol, partly dissected in glycerol and mounted on slides in a glycerolgelatine medium.

The body lenght of adult specimens was measured from the tip of the head to the end of the telson, by tracing the individual's mid-trunk length. A selection of morphological characters and details important for the determination of species and setal formulae follows the terminology suggested by Fišer et al. [2009]. Morphological details were examined using a Zeiss light microscope with magnifications of 100-400x. A morphological description of species is prepared in such a way that it highlights the main taxonomic characters and makes the determination more convenient for specialists, but also more accessible to a wider scientific community. Therefore it is easier for a computerized processing of the data and the development of a multiple access (or polyclave) key using DEscription Language for Taxonomy database software. The advantage of this method is that it allows the researcher to rely on characters that are easy to determine, rather than having to deal with characters that are poorly developed or may not be present in all analyzed species. Characteristics presented here are based on sampled specimens and information from the literature, including drawings of some highly distinctive and stable characters (Fig. 1). Morphological characters that uniquely separate closely related species from each other are presented in bold. Taxonomically important and highly distinctive morphological characters of the species are also listed and summarized briefly in Appendix.
Morphological description of specimens in this study considered some selected body appendages and telson. The following abbreviations are used: mxI - maxillae I; gpI, gpII - gnathopods I and II; ppIII-VII — pereopods IIIVII; plp — pleopod; ep — epimeral plate; upI-III — uropods I-III, T - telson, PMV - the private collection of M. Petković in Valjevo.

\section{Results and Discussion}

A checklist of currently known niphargid species, with their main morphological characters and a list of their geographical locations in the territory of Serbia is presented and further discussed.

\section{SYSTEMATICS}

Class MALACOSTRACA Latreille, 1802 Order AMPHIPODA Latreille, 1816 Family NIPHARGIDAE Bousfield, 1977 Genus NIPHARGUS Schiödte, 1849

\section{Niphargus adbiptus G. Karaman, 1973}

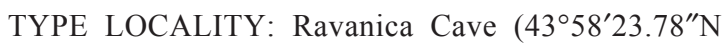
$\left.21^{\circ} 29^{\prime} 52.69^{\prime \prime} \mathrm{E}\right)$, village of Ravanica near Ćuprija, Serbia.

TYPE: Holotype (male $9 \mathrm{~mm}$ long) deposited in G. Karaman's collection in Podgorica, Montenegro.

DIAGNOSTIC CHARACTERS: Adults up to $9 \mathrm{~mm}$ long. Maxilla I outer lobe with 7 spines, each with 1-6 small distomedial denticles. Propodus of gnathopod I with a large spine in corner, with 6 groups of setae posteriorly and 1 dactyl seta anteriorly. Pereopods III, VI and VII without spines on dactyli. Pleopods with an elevated number (6-8) of retinacules. Telson with 3-4 apical spines, 0-1 lateral spines, $0-3$ dorsal spines and $0-1$ mesial spines.

DISTRIBUTION IN SERBIA: Known only from the type locality.

Endemic to Serbia.

Niphargus bajuvaricus Schellenberg, 1932

Niphargus bajuvaricus bajuvaricus Schellenberg, 1932

TYPE LOCALITY: Wells in Moosach near Munich, Germany.

DIAGNOSTIC CHARACTERS: Adults up to $11 \mathrm{~mm}$ long. Maxilla I outer lobe with 7 spines, each with 1-5 small distomedial denticles. Propodus of gnathopod I with 2 large spines in corner, 1 denticulated spine, 8 groups of setae posteriorly and 1 dactyl seta anteriorly. Propodus of gnathopods ovoid, longer than broad. Pereopods with 1 spine on dactylus. Pleopods with 3-4 retinacules. Telson with 2 apical spines, with neither lateral nor dorsal, nor mesal spines.

DISTRIBUTION IN SERBIA: Ranney wells, Prijevor village, near Čačak [G. Karaman, 1989].

WORLD DISTRIBUTION: Austria, Germany, Romania, Serbia and Slovakia.

Niphargus bogdani G. Karaman, 2009

MATERIAL: $1 \sigma^{7}$, PMV, Grlića Cave (= Vrelska Cave).

TYPE LOCALITY: Grlića Cave (= Vrelska Cave), $43^{\circ}$ $33^{\prime} 54.96^{\prime \prime} \mathrm{N} 19^{\circ} 47^{\prime} 5.82^{\prime \prime} \mathrm{E}$, Murtenica village, near Zlatibor, Serbia. 
TYPE: Holotype (female $12.6 \mathrm{~mm}$ long), deposited in G. Karaman's collection in Podgorica, Montenegro.

DIAGNOSTIC CHARACTERS: Adults up to $13 \mathrm{~mm}$ long. Maxilla I outer lobe with 7 spines, each with a small distomedial denticle. Propodus of gnathopod I with a large spine in corner, 3 denticulated spines, 6 groups of setae posteriorly and 9-10 dactyl setae anteriorly. Pereopods with a single spine on dactyli. Pleopods with 2 retinacles. Telson with 4-5 apical spines, 1-2 lateral spines, with neither dorsal nor mesal spines.

DISTRIBUTION IN SERBIA: Known only from the type locality.

Endemic to Serbia.

\section{Niphargus bozanae G. Karaman, 2009}

MATERIAL: $1 \sigma^{7}$, PMV, Rakovička lepotica Cave.

TYPE LOCALITY: Jamina pit, village of Rakova, near Zlatibor, Serbia.

TYPE: Holotype (female $8 \mathrm{~mm}$ long), deposited in G. Karaman's collection in Podgorica, Montenegro.

DIAGNOSTIC CHARACTERS: Adults up to $8 \mathrm{~mm}$ long. Maxilla I outer lobe with 7 spines, each with 1-3 small distomedial denticles. Propodus of gnathopod I with 2 large denticulated spines, 7 groups of setae posteriorly and 6 dactyl setae anteriorly. Pereopods with a single spine on dactyli. Pleopods with 2 retinacles. Telson with 3 apical spines, $0-1$ lateral spines, $2-3$ dorsal spines and a single mesal spine.

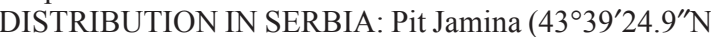
$19^{\circ} 47^{\prime} 27.9^{\prime \prime} \mathrm{E}$ ), village of Rakovica, near Zlatibor [G. Karaman 2009]; valley of Pusta River, Bogujevac village near Kuršumlija [G. Karaman 2012a]; new record: Rakovička lepotica Cave $\left(43^{\circ} 39^{\prime} 38.26^{\prime \prime} \mathrm{N} 19^{\circ} 47^{\prime} 42.38^{\prime \prime} \mathrm{E}\right)$, village of Rakovica, near Zlatibor.

Endemic to Serbia.

Niphargus caspary (Pratz, 1866)

Gammarus caspary Pratz, 1866

Niphargopsis caspary (Pratz, 1866)

Niphargopsis legeri Chevreux, 1922

Niphargopsis trispinosus Dancau et Capuse, 1959

TYPE LOCALITY: Munich, Germany.

DIAGNOSTIC CHARACTERS: Adults up to $6 \mathrm{~mm}$ long. Outer lobe of maxilla I broad, bearing two types of numerous (up to 28 short and 8-9 long) pectinate spines. Propodus of gnathopod I with a large spine in corner, 2 denticulated spines and 4 groups of setae posteriorly. Pereopods III-VII without spine on dactyli. Telson with 3-4 apical spines and 1 plumose seta apically, with neither lateral nor dorsal, nor mesal spines.

DISTRIBUTION IN SERBIA: Ranney wells, village of Prijevor, near Čačak [G. Karaman, 1989]; underground waters of Timok River, village of Šarbanovac, near Zaječar [G. Karaman, 1982b]; Pek River on Golubac - Požarevac road [G. Karaman, 1982b].

WORLD DISTRIBUTION: Austria, Bulgaria, France, Germany, Romania, Serbia and Switzerland.

Niphargus deelemanae G. Karaman, 1973

MATERIAL: 1 , 13 juv., PMV, Velika Cave.

TYPE LOCALITY: Velika Cave, village of Držina, near Pirot, Serbia.
TYPE: Holotype (ovig. female $9 \mathrm{~mm}$ long), deposited in G. Karaman's collection in Podgorica, Montenegro.

DIAGNOSTIC CHARACTERS: Adults up to $9 \mathrm{~mm}$ long. Maxilla I outer lobe with 7 spines, each with 1-3 small distomedial denticles. Propodus of gnathopod I with a large spine in corner and a single denticulated spine, 4-5 groups of setae posteriorly and 1 dactyl seta anteriorly. Pereopods without dactyl spines. Pleopods with 3-4 retinacles. Telson with 3-4 apical spines, single lateral spine, and with neither dorsal nor mesal spines.

DISTRIBUTION IN SERBIA: Velika Cave $\left(43^{\circ}\right.$ $5^{\prime} 41.81^{\prime \prime} \mathrm{N} 22^{\circ} 35^{\prime} 38.36^{\prime \prime} \mathrm{E}$ ), village of Držina, near Pirot [G. Karaman 1973a]; underground waters of the Timok River, village of Šarbanovac, near Zaječar [G. Karaman 2013b]; Bezimena pećina Cave on Mt. Asurovo kale, Zvonačka Banja [G. Karaman 1999].

Endemic to Serbia.

Niphargus euserbicus G. Karaman, 2012

MATERIAL: 1 ㅇ, $1 \bigcirc^{7}, 7$ juv., PMV, Jovanjska Cave; 6 오, Pit Filipov ponor; $2 \sigma^{7} \sigma^{7} 13$ juv., Sinkhole Ponara = Plandište.

TYPE LOCALITY: Jovanjska Cave, village of Jovanja, near Valjevo, Serbia.

TYPE: Holotype (female $15 \mathrm{~mm}$ long), deposited in G. Karaman's collection in Podgorica, Montenegro.

DIAGNOSTIC CHARACTERS: Adults up to $15 \mathrm{~mm}$ long. Maxilla I outer lobe with 7 spines, each with 1-3 small distomedial denticles. Propodus of gnathopod I with a large spine in corner, 4 denticulated spines, 7 groups of setae posteriorly and 12 dactyl setae anteriorly. Pereopods with 1 spine on dactyli. Pleopods with 2 retinacles. Telson with 5 apical spines, 1-2 lateral spines, 2 dorsal spines and 0-2 mesal spines.

DISTRIBUTION IN SERBIA: Jovanjska Cave $\left(44^{\circ} 15^{\prime}\right.$ $\left.2.19^{\prime \prime} \mathrm{N} 19^{\circ} 48^{\prime} 23.61^{\prime \prime} \mathrm{E}\right)$, village of Jovanja, near Valjevo [G. Karaman 2012b]; new records: pit Filipov ponor $\left(44^{\circ} 13^{\prime}\right.$ $\left.15.7^{\prime \prime} \mathrm{N} 19^{\circ} 48^{\prime} 11.7^{\prime \prime} \mathrm{E}\right)$, unnamed village, near Valjevo; sinkhole Ponara $=$ Plandište $\left(44^{\circ} 11^{\prime} 38.9^{\prime \prime} \mathrm{N} 19^{\circ} 59^{\prime} 45.8^{\prime \prime} \mathrm{E}\right)$, village of Robaje, near Valjevo.

Endemic to Serbia.

Niphargus hrabei S. Karaman, 1932

Niphargus tatrensis hrabei S. Karaman, 1932

Niphargus thermalis Dudich, 1941

TYPE LOCALITY: Nana-Parkan, between Komorn and Budapest, Hungary.

DIAGNOSTIC CHARACTERS: Adults up to $10 \mathrm{~mm}$ long. Maxilla I outer lobe with 7 spines, each with small distomedial denticles. Propodus of gnathopod I with a large spine in corner, 4 denticulated spines, 7 groups of setae posteriorly. Pereopod III with 1 , and VII with 4 spines on dactyl. Epimeral plate with a strongly developed distoposterior corner. Pleopods with 2 retinacles. Telson with 3 apical spines, 1 lateral spine, without dorsal spines, and with 1 mesal spine.

DISTRIBUTION IN SERBIA: Danube River [Straškraba, 1972].

WORLD DISTRIBUTION: Austria, Bulgaria, Croatia, Germany, Hungary, Romania, Serbia and Slovakia.

Niphargus illidzensis Schäferna, 1922

Niphargus illidzensis illidzensis S. Karaman, 1932

TYPE LOCALITY: Source of Bosna River (a spring), near Sarajevo, Bosnia and Herzegovina. 
DIAGNOSTIC CHARACTERS: Adults 15 to $25 \mathrm{~mm}$ long. Maxilla I outer lobe with 7 spines, each with small distomedial denticles. Pereopods III-VII with an elevated number of additional spines (4-9) on dactyli. Epimeral plate III with a strongly developed distoposterior corner. Telson with 3-4 apical, 4-5 lateral, 2 dorsal and 2-3 mesal spines.

DISTRIBUTION IN SERBIA: Mt. Avala, near Belgrade [S. Karaman, 1950a, G. Karaman, 1973c].

WORLD DISTRIBUTION: Bosnia and Herzegovina, and Serbia.

\section{Niphargus ivokaramani G. Karaman, 1994}

TYPE LOCALITY: Well, village of Prekonog, near Svrljig, Serbia.

TYPE: Holotype (ovig. female $4.7 \mathrm{~mm}$ long), deposited in G. Karaman's collection in Podgorica, Montenegro.

DIAGNOSTIC CHARACTERS: Adults up to $5 \mathrm{~mm}$ long. Maxilla I outer lobe with 7 spines, each with 1-7 smal distomedial denticles. Propodus of gnathopod I with a large spine in corner, 2 denticulated spines, 4 groups of setae posteriorly and 1 dactyl seta anteriorly. Pereopods without additional spines on dactyli. Pleopods with 2 , rarely 3 , retinacles. Telson with 3 apical spines, 1-2 lateral spines, 0 1 dorsal spine and without mesal spines.

DISTRIBUTION IN SERBIA: Well, village of Prekonog, near Svrljig [G. Karaman, 1994]; village of Izvore, near Svrljig [G. Karaman 1999]; several localities near the city of Bor, Sovac and Fufa Cave [G. Karaman, 1999].

Endemic to Serbia.

\section{Niphargus jugoslavicus G. Karaman, 1982}

TYPE LOCALITY: Underground waters of Trgoviški Timok River, village of Trgovište, near Knjaževac, Serbia.

DIAGNOSTIC CHARACTERS: Adults up to $5 \mathrm{~mm}$ long. Maxilla I outer lobe with 7 spines, each with 1-4 small distomedial denticles. Propodus of gnathopods twice as long as broad, with parallel lateral margins, 2 large spines in corner, 4 groups of setae posteriorly and 2 dactyl setae anteriorly. Pereopods III and IV without spines, the rest with a single spine on dactyli. Pleopods with 2 retinacles. Telson with 3 apical spines, 0-1 lateral spine and with neither dorsal nor mesal spines.

DISTRIBUTION IN SERBIA: Known only from the type locality.

Endemic to Serbia.

Niphargus kragujevensis S. Karaman, 1950

Niphargus kragujevensis kragujevensis S. Karaman, 1950 [Karaman, 1950c]

TYPE LOCALITY: Underground waters, wells and springs of the city of Kragujevac, Serbia.

DIAGNOSTIC CHARACTERS: Adults up to $7 \mathrm{~mm}$ long. Maxilla I outer lobe with 7 spines, each with 1-5 small distomedial denticles. Propodus of gnathopod I with a large spine in corner, 3 denticulated spines, 4 groups of setae posteriorly and 1 dactyl seta anteriorly. Pereopods without additional spines on dactyli. Pleopods with 3-6 retinacles. Telson with 3-4 apical spines, 1-2 lateral spines and with neither dorsal nor mesial spines.

DISTRIBUTION IN SERBIA: Known only from the type locality.
Endemic to Serbia. Description of species is originated after one of the paratype specimens from G. Karaman original collection, (male $7 \mathrm{~mm}$ long), since the original type have been lost.

Niphargus luka G. Karaman, 2012

TYPE LOCALITY: Ranney wells, village of Prijevor, near Čačak, Serbia.

DIAGNOSTIC CHARACTERS: Adults up to $7 \mathrm{~mm}$ long. Maxilla I outer lobe with 7 spines, each with 1-3 small distomedial denticles. Propodus of gnathopod I with a large spine in corner, 2 denticulated spines, 5 groups of setae posteriorly and 5 dactyl setae anteriorly. Pereopods III, IV and VII with 1 spine on dactyli. Pleopods with 2 retinacles. Telson with 4-6 apical spines and with neither lateral nor dorsal, nor mesal spines.

DISTRIBUTION IN SERBIA: Known only from the type locality.

Endemic to Serbia.

Niphargus minor Sket, 1956

Niphargus kochianus minor Sket, 1956

TYPE LOCALITY: Well in Grabje, near Ljubljana, Slovenia.

DIAGNOSTIC CHARACTERS: Adults up to $5 \mathrm{~mm}$ long. Maxilla I outer lobe with 7 spines, each with 1 denticle, and at one lobe with several small distomedial denticles. Propodus of gnathopod I with a large spine in corner, 2 denticulated spines, 4 groups of setae posteriorly and 1 dactyl seta anteriorly. Pereopods III and IV without spines on dactyli, the rest with 1 spine. Pleopods with 2-4 retinacles. Telson with $4-5$, rarely 3 , apical spines, $1-2$ lateral spines, rarely 1 dorsal spine and without mesal spines.

DISTRIBUTION IN SERBIA: Belgrade, Kalemegdan, Rimski bunar well [G. Karaman, 1999].

WORLD DISTRIBUTION: Bosnia and Herzegovina, Croatia, Italy, Serbia and Slovenia.

\section{Niphargus mirocensis Petković et al., 2015}

MATERIAL: 2 +क, 11 juv., PMV, Rakin sinkhole, $1+$, Buronov sinkhole, 1 ㅇ, $1 \sigma^{x}$, Sokolovica Cave.

TYPE LOCALITY: Rakin sinkhole, village of Miroè, near Donji Milanovac, Serbia.

DIAGNOSTIC CHARACTERS: Adults up to $20 \mathbf{~ m m}$ long. Maxilla I outer lobe with 7 spines, each with 2-7 small distomedial denticles. Propodus of gnathopod I with a large spine in corner, 4 denticulated spines, 10 groups of setae posteriorly and 10 dactyl setae anteriorly. Large predatory gnathopods. Propodus large, approximately $0.25 x$ body length. Pereopods with 1 spine on dactyli. Pleopods with 2 retinacles. Telson with 4-5 apical spines, wothout lateral spines, 1 dorsal spine and without mesal spines.

DISTRIBUTION IN SERBIA: Rakin sinkhole $\left(44^{\circ}\right.$ $30^{\prime} 45.11^{\prime \prime} \mathrm{N} 22^{\circ} 16^{\prime} 45.32^{\prime \prime} \mathrm{E}$ ), village of Miroč, near Donji Milanovac [Petković et al., 2015]. New records: Buronov sinkhole $\left(44^{\circ} 33^{\prime} 33.96^{\prime \prime} \mathrm{N} 22^{\circ} 15^{\prime} 39.68^{\prime \prime} \mathrm{E}\right)$, village of Golubinje, near Donji Milanovac; Sokolovica cave $\left(44^{\circ} 30^{\prime} 26\right.$. $\left.36^{\prime \prime} \mathrm{N} 22^{\circ} 20^{\prime} 41.54^{\prime \prime} \mathrm{E}\right)$, village of Brza Palanka, near Donji Milanovac.

Endemic to Serbia. 

1959

Niphargus pecarensis S. Karaman et G. Karaman, 1959

Niphargus pecarensis pecarensis S. Karaman et G. Karaman,

Niphargus tauri pecarensis S. Karaman et G. Karaman, 1959

TYPE LOCALITY: Pečara Dupka Cave near Belogradtschik, Bulgaria.

DIAGNOSTIC CHARACTERS: Adults up to $9 \mathrm{~mm}$ long. Maxilla I outer lobe with 7 spines, each with 1-4 small distomedial denticles. Propodus of gnathopod I with a large spine in corner, 2 denticulated spines, 4 groups of setae posteriorly and 1 dactyl seta anteriorly. Pereopods III and IV without spines, and pereopods V-VII with 1 additional spine on dactyli. Pleopods with 3-4 retinacles. Telson with 1-3 apical spines, 1-2 slender lateral spines and with neither dorsal nor mesal spines.

DISTRIBUTION IN SERBIA: Village of Gabrovnica near Kalna, proximity of the city of Knjaževac [G. Karaman, 1999].

WORLD DISTRIBUTION: Bulgaria and Serbia.

Niphargus ravanicanus S. Karaman, 1943

Niphargus stygius ravanicanus S. Karaman, 1943

MATERIAL: $1 \sigma^{\nearrow}$ PMV, upper lake at source of Grza River.

TYPE LOCALITY: Ravanica Cave, village of Ravanica, near Ćuprija, Serbia.

DIAGNOSTIC CHARACTERS: Adults up to $12 \mathrm{~mm}$ long. Maxilla I outer lobe with 7 spines, each with 1-4 small distomedial denticles. Propodus of gnathopod I with a large spine in corner, 3-4 denticulated spines, 5 groups of setae posteriorly and 2-3 dactyl setae anteriorly. Pereopods with 1 spine on dactyli. Pleopods with 2 retinacles. Telson with 3 apical spines, 2 lateral spines, without dorsal spines and with 1 mesal spine.

DISTRIBUTION IN SERBIA: Ravanica Cave (435' 23.78"N 21 $\left.29^{\prime} 52.69^{\prime \prime} \mathrm{E}\right)$, village of Ravanica, near Ćuprija [G. Karaman, 1973b]. New record: upper lake at source of Grza River $\left(43^{\circ} 53^{\prime} 54.5^{\prime \prime} \mathrm{N} 21^{\circ} 38^{\prime} 57.0^{\prime \prime} \mathrm{E}\right)$, village of Davidovac, near Paraćin.

Endemic to Serbia.

\section{Niphargus remus G. Karaman, 1992}

Niphargus kragujevensis remus G. Karaman, 1992

TYPE LOCALITY: Drinking fountain above the village of Prekonog, near Svrljig, Serbia.

DIAGNOSTIC CHARACTERS: Adults up to $10 \mathrm{~mm}$ long. Maxilla I outer lobe with 7 spines, each with 1 small distomedial denticle, except in one specimen with more than one distomedial denticles. Propodus of gnathopod I with a large spine in corner, 2 denticulated spines, 3 groups of setae posteriorly and 1 dactyl seta anteriorly. Pereopods III and IV without spines, the rest with 1 spine on dactyli. Pleopods with 4-7, rarely 8, retinacles. Telson with 4-5 apical spines, 1-3 lateral spines, with neither dorsal nor mesal spines.

DISTRIBUTION IN SERBIA: Drinking fountain above the village of Prekonog, near Svrljig (G. Karaman 1992]; Lazareva Cave near Zlot [G. Karaman 1999]; smaller spring near source of Visočica River [G. Karaman 1999]; Čika Jovina Cave near Prerast, Homolje Mts [G. Karaman 1999].

Endemic to Serbia.
Niphargus remyi S. Karaman, 1934

Niphargus stygius remyi S. Karaman, 1934

TYPE LOCALITY: Spring in the village of Čedovo, near Sjenica, Serbia.

TYPE: Holotype (female $14 \mathrm{~mm}$ long), deposited in G. Karaman's collection in Podgorica, Montenegro.

DIAGNOSTIC CHARACTERS: Adults up to $14 \mathrm{~mm}$ long. Maxilla I outer lobe with an elevated number (8-9) of stout spiniform spines. Propodus of gnathopod I with a large spine in corner, 3 denticulated spines, 6-8 groups of setae posteriorly and $\mathbf{1 0}$ dactyl setae anteriorly. Pereopods with 1 spine on dactyli. Pleopods with 2 retinacles. Telson with 5 apical spines, 2-3 lateral spines, with neither dorsal nor mesal spines.

DISTRIBUTION IN SERBIA: Known only from the type locality.

Endemic to Serbia.

Niphargus serbicus S. Karaman, 1960

Niphargus (Jovaniphargus) serbicus S. Karaman, 1960

TYPE LOCALITY: Wells in Ćuprija, Serbia.

DIAGNOSTIC CHARACTERS: Adults up to $6 \mathrm{~mm}$ long. Maxilla I outer lobe with 7 spines, each with 1-3 small distomedial denticles. Propodus of gnathopod I with a large spine in corner, 1-4 denticulated spines, 4 groups of setae posteriorly and 1 dactyl seta anteriorly. Pereopods with 1 spine on dactyli. Pleopods with 2-3 retinacles. Telson with 1-2 spines and 3 plumose setae apically, and with neither lateral nor dorsal, nor mesal spines.

DISTRIBUTION IN SERBIA: Wells in Ćuprija [S. Karaman, 1960]; Valjevo [G. Karaman, 1983]; village of Donja Gorevica, near Čačak [G. Karaman 1983]; Pek River on Golubac - Požarevac road [G. Karaman, 1983]; underground waters of Trgoviški Timok River, village of Trgovište, near Knjaževac [G. Karaman, 1983].

WORLD DISTRIBUTION: Austria, Bosnia and Herzegovina, Croatia, Montenegro, Romania, Serbia and Slovakia.

Niphargus smederevanus S. Karaman, 1950

TYPE LOCALITY: Fountain in the city of Smederevo, Serbia [Karaman, 1950b].

DIAGNOSTIC CHARACTERS: Adults up to $11 \mathrm{~mm}$ long. Maxilla I outer lobe with 7 spines, each with 1-3 small distomedial denticles. Propodus of gnathopod I with a large spine in corner, 3 denticulated spines, 6 groups of setae posteriorly and 6-7 dactyl setae anteriorly. Pereopods III and IV with 2 spines, the rest with 1 spine on dactyli. Telson with 3 apical spines, 1 lateral spine, 2-4 dorsal spines and 0-1 mesal spines.

DISTRIBUTION IN SERBIA: Known only from the type locality.

Endemic to Serbia.

Niphargus valachicus Dobreanu et Manolache, 1933

Niphargus mediodanubialis Dudich, 1941

Niphargus tatrensis valachicus Dobreanu et Manolache, 1933

TYPE LOCALITY: Bucharest, Romania.

DIAGNOSTIC CHARACTERS: Adults up to $15 \mathrm{~mm}$ long. Maxilla I outer lobe with 7 spines, each with 1-3 small distomedial denticles. Propodus of gnathopod I with a large 


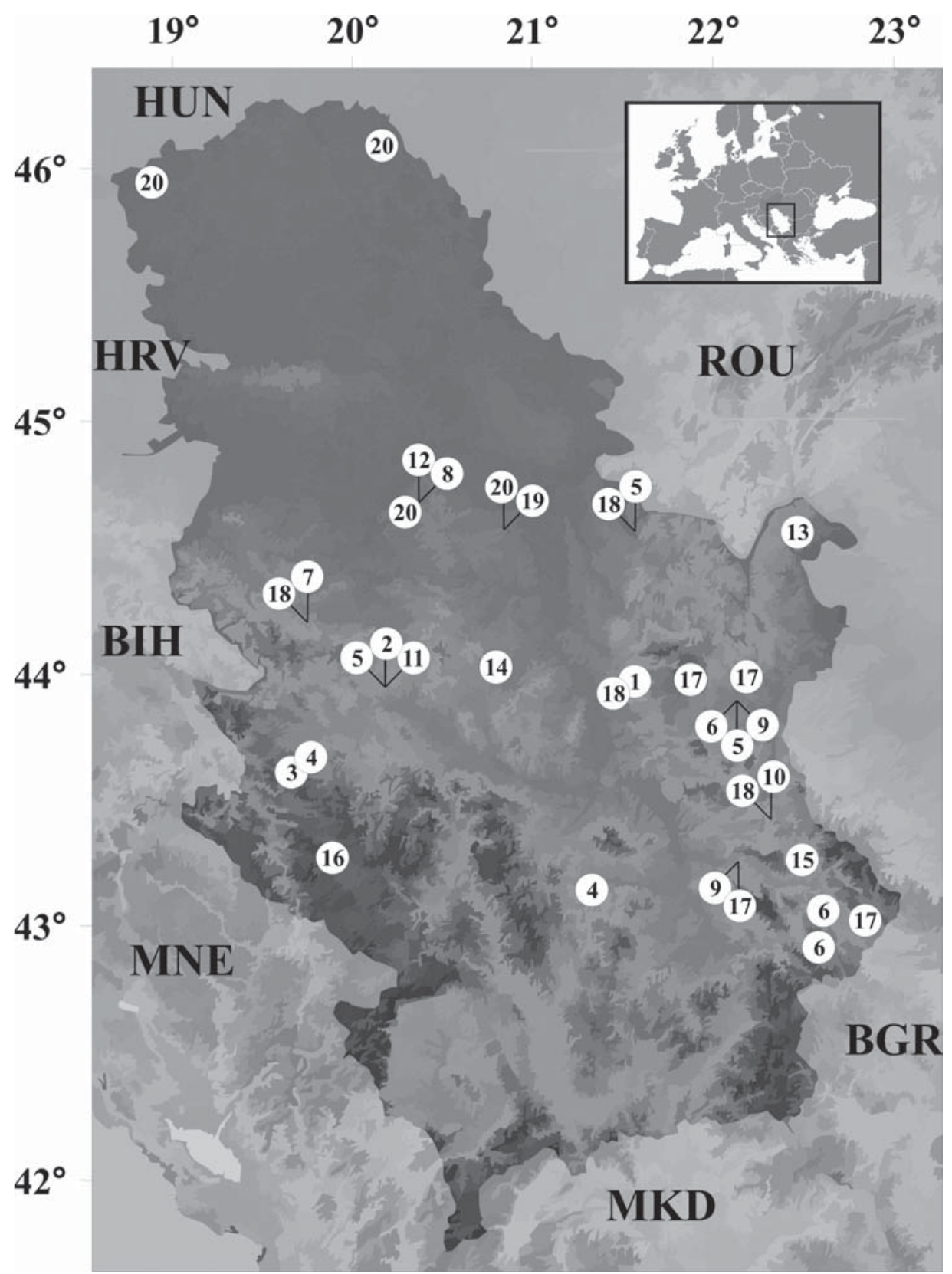

Fig. 2. Localities of Niphargus species found in Serbia: $1-N$. adbiptus and N. ravanicanus, $2-N$. bajuvaricus, $3-N$. bogdani, $4-$ $N$. bozanae, $5-N$. caspary, $6-N$. deelemanae, $7-N$. euserbicus, $8-N$. illidzensis, $9-N$. ivokaramani, $10-N$. jugoslavicus, 11 - N. luka, $12-N$. minor, $13-N$. mirocensis, $14-$ N. kragujevensis, $15-N$. pecarensis, $16-N$. remyi, $17-N$. remus, $18-N$. serbicus, $19-N$. smederevanus, $20-N$. valachicus.

Рис. 2. Местонахождения видов Niphargus Сербии: $1-$ N. adbiptus и N. ravanicanus, $2-N$. bajuvaricus, $3-N$. bogdani, $4-$ $N$. bozanae, $5-N$. caspary, $6-N$. deelemanae, $7-N$. euserbicus, $8-N$. illidzensis, $9-N$. ivokaramani, $10-N$. jugoslavicus, $11-$ N. luka, $12-N$. minor, $13-N$. mirocensis, $14-N$. kragujevensis, $15-N$. pecarensis, $16-N$. remyi, $17-N$. remus, $18-N$. serbicus, $19-N$. smederevanus, $20-N$. valachicus.

spine in corner, 2-3 denticulated spines, 7-8 groups of setae posteriorly and $\mathbf{8}-\mathbf{1 0}$ dactyl setae anteriorly. Pereopods III-VII with an elevated number of additional spines (610) on dactyli. Pleopods with $2-3$ retinacles. Telson with 3 apical spines, 1 lateral spine, 1 dorsal spine and without mesal spines.

DISTRIBUTION IN SERBIA: Danube area, Godominsko polje, near Smederevo [S. Karaman, 1950c]; ranney wells in the area of Makiš, Belgrade [S. Karaman 1950a]; Zlatica River, village of Vrbica, near Kikinda [Marković et al., 2018] (45 58 $\left.46.9^{\prime \prime} \mathrm{N} 20^{\circ} 19^{\prime} 44.7^{\prime \prime} \mathrm{E}\right)$; Plazović River, village of Bački breg, near Sombor [Marković et al., 2018] $\left(45^{\circ} 54^{\prime} 28.00^{\prime \prime} \mathrm{N} 18^{\circ} 58^{\prime} 25.08^{\prime \prime} \mathrm{E}\right)$

WORLD DISTRIBUTION: Bulgaria, Croatia, Czech Republic, Hungary, Iran, Romania, Serbia, Slovakia, Slovenia and Turkey. 


\section{Remarks on the distribution of taxa}

The Serbian part of the Balkan Peninsula is characterized by the presence of a stygobiotic fauna with rather disjunct distributions in the area between the Dinarides and Carpatho-Balkan Mountains (Fig. 2), occupying an interesting area in the vicinity of the Carpathian Mountains, Dinaric Alps, Balkan Mountains and the former Paratethys. Our research on the subterranean fauna, still ongoing, confirms the great diversity of Niphargus populations in different caves and groundwater habitats in Serbia.

The first published record was for $N$. illidzensis, reported by S. Karaman from a spring on Mt. Avala near Belgrade in 1932 [S. Karaman, 1932]. Later, $N$. adbiptus [G. Karaman, 1973b] and N. ravanicanus [G. Karaman, 1973b] were collected in the Ravanička Cave in the early 1940s. That time, only $N$. adbiptus was described, while N. ravanicanus [G. Karaman, 1973b] was overlooked because only juveniles had been caught. All further attempts to sample new material of these species have been unsuccessful, possibly due to pollution of the subterranean water from the surface (the nearby stream has usually been polluted by organic matter during the summer). In addition, small ponds remaining in the cave after the rainy season are usually loaded with guano, making those habitats unsuitable for amphipods. However, during an expedition of the "Josif Pančić" Student Biological Society from Belgrade, one specimen of $N$. ravanicanus was collected in an upper artificial lake in the valley of Grza River [Karaman, 1973b]. The animal was probably washed out from the cave 'Pećina na vrelu Grze' by a strong flood.

Niphargus bozanae [G. Karaman, 2009] was described from the type locality on Mt. Zlatibor in the western part of Serbia; the description of the subspecies $N$. bozanae omnivagus [Karaman, 2012a] in the southern part of the country increases its distribution area in Serbia.

Niphargus luka [G. Karaman, 2012b], N. jugoslavicus [G. Karaman, 1982a], N. kragujevensis [S. Karaman, 1950c], N. remyi [S. Karaman, 1934] and $N$. smederevanus [S. Karaman, 1950b] are steno-endemic species recorded only from the type localities in Serbia. The original descriptions of their localities were neither well documented nor sufficiently detailed, so the locations given in the literature cannot be exactly relocated. Some of those localities were visited and sampled a long time ago, which now makes the finding of the exact localities even more difficult.

The karstic area known as 'Valjevski kras' is the best explored subterranean region in Serbia. In addition to the type locality (Jovanjska Cave), the endemic species N. euserbicus [G. Karaman, 2012b] has been detected at several sites in the vicinity. This supports our assumption that the given taxon inhabits the entire area of "Valjevski kras" in western Serbia.

Niphargus mirocensis [Petković et al., 2015] is the only Serbian niphargid species for which a phylogenet- ic analysis has been performed to date. The obtained results suggest that $N$. mirocensis is a sister species to $N$. stenopus Sket, 1960, described from SE Slovenia [Sket, 1960]. N. mirocensis was detected in the Rakin sinkhole, the Buronov sinkhole and a spring in the Sokolovica Cave. All of those localities on Mt. Miroč represent the same Balkano-Carpathic karstic area. It was expected that this species could also be found in the adjoining Bele Vode caves, the Ibrin and the Faca Šore karst funnels.

N. serbicus [S. Karaman, 1960] is a species with a wide range and the type locality in Serbia. It has also been observed in subterranean waters of Croatia, Bosnia and Herzegovina, Slovenia, Austria and Romania. Other species with the similarly wide range, including Serbia, are $N$. hrabei [Karaman, 1932], N. minor [Sket, 1956], N. bajuvaricus [Schellenberg, 1932], N. caspary [Pratz, 1866] and N. valachicus [Dobreanu, Manolache, 1933].

According to the literature [S. Karaman, 1950a], $N$. illidzensis was mentioned from the area of Topčider and Mt. Avala near Belgrade. However, this species has again been sampled neither in the territory of Belgrade nor other parts of Serbia. On the other hand, the type locality of this species is in the proximity of Sarajevo in central Bosnia and Herzegovina, in the valley of the Bosna River near the spa Ilidža, where the species still exists [Trožić-Borovac et al., 2012]. Geographically, the type locality is a part of the western Dinaric region (Croatia, Bosnia and Herzegovina, Montenegro), where the existence of several taxa of the Niphargus illidzensis-complex is documented [Karaman, 1950a]. There is a possibility that the record from Serbia is misleading, so the existence of this species in Serbia needs to be further explored and confirmed.

Apart from the species listed above, some other niphargid species have been recorded in surrounding countries on both western and eastern sides, beyond the current borders of the administrative territory of Serbia. Examples of such species are Niphargus multipennatus Sket, 1956, N. parapupetta G. Karaman, 1984, N. pupetta Sket, 1962, N. pannonicus S. Karaman, 1950, N. petrosani Dobreanu et Manolache, 1933. It is safe to assume that they may also inhabit the Serbian territory, and this possibility should be a guideline for future investigations.

\section{Conclusions}

Currently, 22 niphargid species are known to occur in Serbia, including 14 steno-endemic species. The real diversity of the genus is most likely to be higher, and it is expected to increase with further explorations of subterranean fauna. Other species, known from the neighboring areas, are also expected to inhabit subterranean waters in Serbia. For future studies on the genus Niphargus, it will be crucial to compile a database using DEscription Language for Taxonomy (DELTA) software for all Serbian taxa, characterize them phylo- 
genetically and determine which, if any, are cryptic. Cryptic diversity in macro-stygobionts is already well documented [Trontelj et al., 2009], this also being the case for some Serbian taxa ranked as subspecies, such as $N$. bozanae and $N$. bozanae omnivagus, or the case of $N$. deelemanae deelemanae and $N$. deelemanae grex. Even after extensive investigations by outstanding amphipod taxonomists, e.g., Stanko and Gordan Karaman, for a long period, there are still new and surprising records, such as the recently described new species: N. euserbicus [G. Karaman, 2012b], N. luka [G. Karaman, 2013a] and N. mirocensis [Petković et al., 2015].

Acknowledgements. This work is part of MP's doctoral thesis. We thank the members of the "Vladimir Mandic Manda" Society of Young Researchers from Valjevo for their assistance with sampling. Data provided by Academician and Professor Emeritus Dr. Gordan S. Karaman were highly appreciated and useful for the realization of this study, and we thank him for that. We also thank the peer reviewers and Sergei Golovatch (Moscow) for their valuable remarks and corrections to the text. The authors are also grateful to Mr. Raymond Dooley for his help in preparing the English version of the manuscript. This publication was partly supported by the Serbian Ministry of Education, Science and Technology (Grant No. 173038).

\section{References}

Dobreanu E., Manolache C. 1933. Beitrag zur Kenntnis der Amphipodenfauna Rumäniens // Notat. Biol. Vol.1. No.3. S.103108.

Fišer C., Trontelj P., Luštri R., Sket B. 2009. Toward a unified taxonomy of Niphargus (Crustacea: Amphipoda): a review of morphological variability // Zootaxa. Vol.2061. P.1-22.

Horton T., Lowry J., De Broyer C., Bellan-Santini D., Coleman C.O., Corbari L., Costello M.J., Daneliya M., Dauvin J-C., Fišer C., Gasca R., Grabowski M., Guerra-García J.M., Hendrycks E., Hughes L., Jaume D., Jazdzewski K., Kim Y-H., King R., Krapp-Schickel T., LeCroy S., Lörz A-N., Mamos T. Senna A.R., Serejo C., Sket B., Souza-Filho J.F., Tandberg A.H., Thomas J.D., Thurston M., Vader W., Väinölä R., Vonk R., White K., Zeidler W. 2019. World Amphipoda Database. Accessed at http://www.marinespecies.org/amphipoda on 2019 10-08. doi:10.14284/368

Jazdzewski K., Kupryjanowicz J. 2010. One more fossil niphargid (Malacostraca: Amphipoda) from Baltic amber // Journal of Crustacean Biology. Vol.30. No.3. P.413-416.

Karaman G.S. 1973a. Contribution to the knowledge of the Amphipoda. Two new species of family Gammaridae from Yugoslavia, Niphargus deelemaniae n. sp. and Typhlogammarus algor, n. sp. // Archiv für Hydrobiologie. Vol.72. No.4. P.490500.

Karaman G.S. 1973b. Contribution to the knowledge of the Amphipoda. On three Niphargus species (Fam. Gammarida) from the Balkans // International Journal of Speleology. Vol.5. P.143152.

Karaman G.S. 1973c. Contribution to the knowledge of the Amphipoda. Two subterranean Niphargus species from Yugoslavia, N. stankoi, n. sp. and N. illidzensis Schäferna (Fam. Gammaridae) // Glasnik Republièkog Zavoda za Zaštitu Prirode. Vol.6. P.35-57.

Karaman G.S. 1982a. Contribution to the knowledge of the Amphipoda. One new subterranean amphipod from Yugoslavia, Niphargus jugoslavicus, n. sp. (Fam. Gammaridae) // Poljoprivreda i Šumarstvo, Titograd. Vol.28. No.2. P.119-130.
Karaman G.S. 1982b. Contribution to the knowledge of the Amphipoda. First discovery of genus Niphargopsis Chevr. 1922 in Yugoslavia with revision of the genus (Fam. Gammaridae) // Poljoprivreda i Šumarstvo, Titograd. Vol.28. No.2. P.87-103.

Karaman G.S. 1983. Contribution to the knowledge of the Amphipoda. Niphargus serbicus S. Kar. 1960 in Yugoslavia with remarks on the subterranean amphipods in Serbia (1929) // Drugi simpozijum o fauni SR Srbije - Zbornik, Beograd. P.6770 .

Karaman G.S. 1984. Contribution to the knowledge of the Amphipoda. Description of several new Niphargus species (Gammaridea, Niphargidae) from Southern Europe // Poljoprivreda i Šumarstvo, Titograd. Vol.30. P.2-3.

Karaman G.S. 1989. Contribution to the knowledge of the Amphipoda. Taxonomical investigations on Niphargus bajuvaricus Schell. 1932 and its subspecies // Glasnik Republièkog Zavoda za Zaštitu Prirode. Vol.22. P.95-111.

Karaman G.S. 1992. Contribution to the knowledge of the Amphipoda. On some interesting Niphargus species from Europe (Amphipoda Gammaridea, fam. Niphargidae) // Glasnik Republièkog Zavoda Zaštite Prirode - Prirodnjaèkog Muzeja Podgorica. Vol.25. P.41-52.

Karaman G.S. 1994. Contribution to the knowledge of the Amphipoda. Further studies on genus Niphargus Schioedte 1849 from Europe, $N$. ivokaramani, n. sp. and $N$. danielopoli, n. sp. // Montenegrin Academy of Sciences and Arts: Glasnik of the Section of Natural Sciences. Vol.10. P.113-133.

Karaman G.S. 1999. The endemic Amhipod species (Crustacea) from Serbia and adjacent region // VII Ekološka Istina. P.166169.

Karaman G.S. 2009. Contribution to the knowledge of the Amphipoda. Two new species of the genus Niphargus Schiodte, 1849 (Crustacea Amphipoda, Niphargidae) from the caves of Serbia // Montenegrin Academy of Sciences and Arts: Glasnik of the Section of Natural Sciences. Vol.18. P.71-92.

Karaman G.S. 2012a. Contribution to the knowledge of the Amphipoda. Further investigations of the subterranean genus Niphargus Schiödte, 1849 (fam. Niphargidae) in Serbia // Agriculture \& Forestry. Vol.58. No.2. P.45-64.

Karaman G.S. 2012b. Contribution to the knowledge of the Amphipoda. Investigations on two subterranenan species of the family Niphargidae (Gammaridea) from Serbia, Niphargus remyi S. Kar. 1934 and N. euserbicus, sp. n. // Poljoprivreda i Šmarstvo [Agriculture \& Forestry]. Vol.58. No.3. P.63-95.

Karaman G.S. 2013a. Contribution to our knowledge of the Amphipoda. Discovery of a new subterranean member of the family Niphargidae from Serbia, Niphargus luka sp. n. // Biologia Serbica. Vol.35. No.1-2. P.31-42.

Karaman G.S. 2013b. Contribution to the knowledge of the Amphipoda. On two members of the genus Niphargus Schiödte, 1849 (Crustacea: Niphargidae) from the Balkan Peninsula, $N$. deelemanae grex ssp. and N. jurinaci S. Kar. 1950 // Acta Entomologica Serbica. Vol.18. No.1/2. P.207-235.

Karaman S.L. 1932. Beitrag zur Kenntnis der Süsswasser-Amphipoden // Prorodoslovne Razprave. Vol.2. P.179-232.

Karaman S. 1934. VI Beitrag zur Kenntnis jugoslawischer Suesswasseramphipoden // Zoologischer Anzeiger. Bd.107. S.325333.

Karaman S. 1950a. Niphargus illidzensis Schäferna i njegovi srodnici u Jugoslaviji. O nekim amfipodima - izopodima Balkana i o njihovoj sistematici // Srpska Akademija nauka Beograd. Odjeljenje prirodno-matematièkih nauka. Posebna izdanja. T.163. P.51-86 [in Serbian].

Karaman S. 1950b. N. smederevanus n. sp. iz severne Srbije. O nekim amfipodima - izopodima Balkana i njihovoj sistematici // Srpska Akademija nauka Beograd. Odjeljenje prirodnomatematièkih nauka. Posebna izdanja. T.163. P.1-10 [in Serbian].

Karaman S. 1950c. Ueber die kleinen Niphargus-Arten Jugoslaviens. O nekim Amfipodima-Isopodima Balkana i o njihovoj široj sistematiki // Posebna izdanja. Odeljenje Prirodno matematièkih nauka. Vol.163. P.87-99 [in Serbian]. 
Karaman S. 1960. Weitere Beiträge zur Kenntnis des jugoslavischen Niphargiden // Glasnik Prirodnjaèkog Muzeja u Beogradu B. Vol.15. P.75-90.

Koch C.L. 1837. Deutschlands Crustaceen, Myriapoden und Arachniden. Regensburg. Heft 5 .

Lefébure T., Douady C.J., Gouy M., Trontelj P., Briolay J., Gibert J. 2006. Molecular phylogeography of Niphargus virei // Molecular Ecology Vol.15. P.1797-1806. https://doi.org/10.1111/ j.1365-294X.2006.02888.x

Lefébure T., Douady C.J., Malard F., Gibert J. 2007. Testing dispersal and cryptic diversity in a widely distributed groundwater amphipod (Niphargus rhenorhodanensis) // Molecular Phylogenetics and Evolution. Vol.42. P.676-686. https://doi.org/ 10.1016/j.ympev.2006.08.020

Marković V., Novaković B., Ilić M., Nikolić V. 2018. Epigean niphargids in Serbia: New records of Niphargus valachicus Dobreanu \& Manolache, 1933 (Amphipoda: Niphargidae), with notes on its ecological preferences // Acta Zoologica Bulgarica. Vol.70. No.1. P.45-50.

Mathieu J., Jeannerod F., Hervant F., Kane T.C. 1997. Genetic differentiation of Niphargus rhenorhodanensis (Amphipoda) from interstitial and karst environments // Aquatic Sciences. Vol.59. P.39-47. https://doi.org/10.1007/BF02522549

Meleg I.N., Zakšek V., Fišer C., Kelemen B.S., Moldovan O.T. 2013. Can environment predict cryptic diversity? The case of Niphargus inhabiting Western Carpathian groundwater // PLoS ONE. Vol.8. No.10. P.1-13. http://dx.doi.org/10.1371/ journal.pone.0076760

Ntakis A., Anastasiadou C., Zakšek V., Fišer C. 2015. Phylogeny and biogeography of three new species of Niphargus (Crustacea: Amphipoda) from Greece // Zoologischer Anzeiger Vol.255. P.32-46. http://dx.doi.org/10.1016/j.jcz.2015.02.002

Petković M., Delić T., Lučić L., Fišer C. 2015. Description of a new species of Niphargus (Crustacea: Amphipoda: Niphargidae): the first record of a lake ecomorph in the Carpathian Mountains // Zootaxa. Vol.4027. No.1. P.117-129. http:// dx.doi.org/10.11646/zootaxa.4027.1.5

Pratz E. 1866. Über einige im Grundwasser lebende Tiere. Beiträge zur Kenntnis der unterirdischen Crustaceen // Saint Petersburg.
Schellenberg A. 1932. Vier blinde Amphipodenarten in einem Brunnen Oberbayerns // Zoologischer Anzeiger. Bd.98. S.131139.

Sket B. 1956. Einge neue Formen der Malacostraca (Crust.) aus Jugoslawien // Bulletin Scientifique. Vol.3. No.3. S.70-71.

Sket B. 1960. Einige neue Formen der Malacostraca aus Jugoslawien III // Bulletin Scientifique Yougoslavie. Vol.5. No.3. S.7375 .

Sket B. 1962. Karamaniella pupetta n.g., n.sp., ein neuer Amphipode aus Slovenien // Izdanija, publ. Zavoda za ribarstvo NRM Skopje. Vol.3. No.2. S.27-31.

Straškraba M. 1972. The current state of our knowledge of the Niphargus genus in Czechoslovakia and neighboring countries // Ruffo S. (ed.). Proceedings of the 1st International Conference on the genus Niphargus. Mus. Civ. St. Nat. Verona. Same. Fuori 5. P.35-46.

Trontelj P., Douady C.J., Fišer C., Gibert J., Gorièki Š., Bure T.L., Sket B., Zakšek V. 2009. A molecular test for cryptic diversity in ground water: how large are the ranges of macro-stygobionts? // Freshwater Biology. Vol.54. P.727-744. http://dx.doi. org/10.1111/j.1365-2427.2007.01877.x

Trožić-Borovac S., Bašić L., Hafner D. Mušović A. 2012. Endemic amphipod Niphargus ilidzensis Shäfferna 1922, (Crustacea: Amphipoda) within the protected area of Canton Sarajevo // Works of the Faculty of Forestry University of Sarajevo. Issue 2. P73-87.

Väinölö R., Witt J.D.S., Grabowski M., Bradbury J.H., Jazdzewski K., Sket B. 2008. Global diversity of amphipods (Amphipoda; Crustacea) in freshwater // Hydrobiologia. Vol.595. P.241255. http://dx.doi.org/10.1007/978-1-4020-8259-7_27

Zagmajster M., Eme D., Fišer C., Galassi D., Marmonier P., Stoch F., Cornu J.F., Malard F. 2014. Geographic variation in range size and beta diversity of groundwater crustaceans: insights from habitats with low thermal seasonality // Global Ecology and Biogeography. Vol.23. No.10. P.1135-1145. http:// dx.doi.org/10.1111/geb.12200

Responsible editor S.I. Golovatch 